Graduate Institute of

International and Development Studies Working Paper

No: $11 / 2013$

\title{
Understanding Rating Addiction: US Courts and the Origins of Rating Agencies' Regulatory License (1900-1940)
}

\author{
Marc Flandreau \\ Graduate Institute of International and Development Studies \\ Joanna Kinga Sławatyniec \\ Graduate Institute of International and Development Studies
}

\begin{abstract}
This paper discusses the "regulatory license" view that reliance by regulators on the output of rating agencies in the 1930s "caused" the agencies to become a central part of the fabric of the US financial system. Exploring pre-1930 court records, we find evidence of a growing reliance on the agencies that pre-dates the regulatory moves of the 1930s. We argue that courts began using ratings as financial community produced norms of prudence, providing a novel interpretation of the emergence of rating in financial systems as a product of trustee law. We remark that this created "a legal license" problem, creating incentives and conflicts of interest not unlike those which modern observers usually associate with regulation in the subprime crisis.
\end{abstract}

(C) The Authors.

All rights reserved. No part of this paper may be reproduced without the permission of the authors. 


\title{
Understanding Rating Addiction: US Courts and the Origins of Rating Agencies' Regulatory License (1900-1940)
}

\author{
Marc Flandreau and Joanna Kinga Sławatyniec ${ }^{\star}$ \\ April 2013
}

\begin{abstract}
This paper discusses the "regulatory license" view that reliance by regulators on the output of rating agencies in the 1930s "caused" the agencies to become a central part of the fabric of the US financial system. Exploring pre-1930 court records, we find evidence of a growing reliance on the agencies that pre-dates the regulatory moves of the 1930s. We argue that courts began using ratings as financial community produced norms of prudence, providing a novel interpretation of the emergence of rating in financial systems as a product of trustee law. We remark that this created "a legal license" problem, creating incentives and conflicts of interest not unlike those which modern observers usually associate with regulation in the subprime crisis.
\end{abstract}

^ Flandreau is Professor of International Economics, Graduate Institute for International Studies and Development. Sławatyniec is PhD candidate, International History, Graduate Institute for International Studies and Development. The authors are grateful to Andrew Verstein for insightful comments on an earlier draft. We also thank Laura Rosner for excellent research assistance. 
There does exist a widespread view about rating agencies, first proposed by Harold (1938). It is that some sort of revolution occurred during the 1930s in social uses of ratings. It would have come, initially, in a rather technical way when on September 11, 1931, the Comptroller of the Currency William Pole (the man in charge of supervising banks with a federal charter or "national banks") announced that he had started relying on ratings to enable banks to depart from "mark to market". Marking to market is an accounting procedure whereby securities held are booked at market prices. But in a plummeting market as was the case in the Summer of 1931 this risked jeopardizing the solvency of banks, because it would amount to banks taking massive losses. Technically, the Pole ruling did this: Banks were now enabled to book at face value a number of reputedly safe and sound securities (even if such securities were suffering heavy discounts in trading). This included US Government, State and Municipal bonds and all bonds enjoying any of the "first four ratings by statistical corporations" (as they were then known), by which were meant the likes of Moody's and Standard Statistics. ${ }^{1}$ By contrast, securities with lower grades, were marked to market.

This move, according to Harold, was a first step in a succession of far-reaching arrangements that ingrained ratings in the fabric of the US financial system. Indeed, following the Banking Act of 1933 and introduction of deposit insurance, ratings were used as a way to monitor the quality of banks' portfolios and essentially, supervise them (Harold 1938). Both critics and supporters or insiders of rating agencies agree with this idea of a series of epoch making decisions to which the modern financial system would be heir. A Moody's Investors Service memorandum traces the origins of the modern cut-off between "investment grade" (the four top notches mentioned in the Pole ruling) and "speculative grade" (those below) to the announcement of September 11, 1931 (Fons 2004). Likewise, according to Frank Partnoy (1999, 2006), an outspoken and prescient critic of the agencies, the regulatory moves initiated in 1931 gave the agencies ownership of a valuable resource. They would have controlled as a result the marketability of securities, something he calls a "regulatory license." This created conflicts of interest since rating agencies would derive revenues from certifying that individual securities be proper fodder for safety hungry institutional investors. This enormous power would have held the promise of a disaster when rating agencies succumbed to the temptation of rating the new subprime securities in the 2000 s even when they hardly

\footnotetext{
${ }^{1}$ The source article was an article in the New York Sun, of September 11, 1931 (from which we draw our quotation). Subsequent appeared in the Wall Street Journal ("50\% of bank bond valuations safe", September 12) and the Commercial and Financial Chronicle ("Comptroller of Currency Liberalizes Rules on Depreciated Government, State and Municipal Bonds", September 12).
} 
understood them. In other words, according to the regulatory license view, transformations in the social uses of rating in the 1930s would have been the original sin that eventually caused the subprime crisis.

Suggestively, this reading of the crisis is endorsed by rating agencies such as Moody's, whose officials have recently emphasized that they long for the more rapid removal of the regulatory license (because it would clarify their responsibility). ${ }^{2}$ In fact, the modern debate exhibits a curious twist, whereby rating agencies advocate removal of reference to their grades for regulatory purposes while reports accumulate on the difficulty of extirpating rating from regulatory frameworks and prudential supervision. ${ }^{3}$ It looks as if our societies have become addict to ratings, enabling providers of rating to be comfortable with the prospect of an ostensible reduction of their role - as if they knew better.

To understand the logic at work, it is important to take a harder, closer look at the rise of rating. Indeed, if one examines more carefully the historical record on the alleged 1931 turning point, one is bound to realize that the "landmark" decision by the Comptroller of the Currency was made in a language that evinced familiarity on behalf of the bank examiners (to whom the instruction was directed): The wording of the original instruction (a copy of which is kept in the records of the US Treasury in NARA) assumed that examiners knew what a rating was and how to use it, and it also identified four agencies as - legitimate? -- providers or such grades ${ }^{4}$. The rather concise instruction it gave provided no further elaboration, and this implies that Pole understood bank examiners understood how to work with the agencies' manuals and grades. Likewise, it appears from archival evidence that the instruction dated back to August 29, two weeks before the official announcement. By announcing it about two weeks later and emphasizing that he would rely on rating agencies' grades, Pole was probably attempting to reassure markets. But how could this possibly be reassuring if nobody knew

\footnotetext{
${ }^{2}$ Richard Cantor, "Sovereign credit ratings", address to the BIS Seminar on Sovereign Risk: A World Without Risk-Free Assets?”, Basel, 8 January 2013.

${ }^{3}$ For instance, "Trouble of removing ratings highlighted by SEC", May 5, 2011, http://www.risk.net/riskmagazine/news/

${ }^{4}$ Correspondence with the Office of the Comptroller of Currency, August 29, 1931; The U.S. National Archives and Records Administration - Dept. of the Treasury Office of the Comptroller of Currency; National Archives Building, Washington, DC. The instruction (is dated August 29, 1931 - almost two weeks before the official announcement before the press). The instruction reads: "TO ALL CHIEF NATIONAL BANK EXAMINERS: With further reference to bond depreciation, you are requested immediately upon reception of this letter, to instruct your examiners to show the rating of each issue on the margin opposite the 'estimated market value'. Please also explain to them that, until otherwise instructed, this office will not require the charge off of any depreciation on bonds of the United States Government, of states counties, or municipalities thereof, or other bonds which have the following rating [there follows a table showing the top rating for four different agencies, with the corresponding "natural language" interpretation, ranging from "High Class" (or AAA as per Moody's) to "Good" (or BBB)"]
} 
what ratings were? These facts do not square very neatly with the view of a revolution brought about by a 1931 ruling coming "out of the blue".

This paper makes a contribution by providing a novel perspective on the rise of rating as a regulatory tool. We suggest that, before regulatory reliance on rating was acted by US authorities there already existed a similar mechanism at work, which may be called by analogy to Partnoy, "legal license." As we proceed to argue, the regulatory license built on the legal license, which the agencies had received long before 1931.

Using reports from court cases quoting the statistical corporations, we provide evidence of a legal license in the increasing incidence of courts' quotations of the agencies' output in truth discovery, damages assessment etc., as well as in the connotations of the language used in opinions rendered during the period 1900-1940. This trend began before the 1930s. ${ }^{5}$ In fact, by the time Pole issued his "landmark" ruling, concepts of financial prudence had already made their way in US courts, which relied on the output of the statistical organizations to assess the behavior of trustees, bankers and brokers. The regulatory moves of the 1930s were significant in that they replaced court-enforced assessments by law making, regulation and regulatory agencies, not by placing the output of the agencies at the center of the US financial system, for it was already there.

\section{US Courts and Statistical Agencies' Output 1900-1940}

In this section, we examine a population of relevant cases found to have quoted at least one relevant statistical organization during the period 1900-1940. The source is Westlaw. Relevant rating agencies include the main players on the market during this time span, Moody's, Poor's, Fitch and Standard Statistics. Relevant cases are those including language implying that one agency output is used as a tool in truth discovery, assessment of damages, etc. ${ }^{6}$ An identical Westlaw query was applied uniformly to the four agencies. ${ }^{7}$ It returned respectively 216 hits for Moody's, 43 for Poor's, 15 for Standard Statistics and 4306 for Fitch. Output was then manually purged, ${ }^{8}$ yielding a total of 52 cases with 27 quoting

\footnotetext{
${ }^{5}$ We limit ourselves to Federal Cases solely (see Appendix). Evidence in support of statistical corporations' role within the US legal and political system before 1930s however is also to be found elsewhere. For example, here is an excerpt from a May 2, 1922 US Senate Record (Senator William H. King of Utah speaking): "In 1918 the Union Carbide Co. was absorbed by the Union Carbide \& Carbon Corporation. I have examined Moody's Manual and I also have here the Directory of Directors in the City of New York, 1919-20, which seems to be an accepted authority." Congressional Record-Senate, 62 Cong. Rec. 6172 (1922): 6196.

${ }^{6}$ The use of ratings in legal decisions is briefly mentioned in Harold (1938) who gives two cases where

${ }^{7}$ The form of the query was "Moody's" \& da(aft $1900 \&$ bef 1940). See appendix for details.

${ }^{8}$ A case was deemed unrelated either because it would involve a homonym of a rating agency (e.g. Lawson v. State, which mentioned the theft of Mrs. Poor's car: Lawson v State, 161 Miss. 719, 138 So. 361, (1931) or because the rating agency itself would be quoted but for a reason other than being an authority (e.g. in an appeal
} 
Moody's, 23 quoting Poor's and 14 quoting Standard Statistics (multi-quotation occurred so that number of cases quoting a given agency need not add up to the total of cases quoting a least one agency). Fitch had to be dropped from the analysis because almost all the many cases retrieved were unrelated to the rating agency. ${ }^{9}$ There was a total of 42 cases quoting at least one agency.

Figure 1. Number of Cases Per Period (individual and joint)

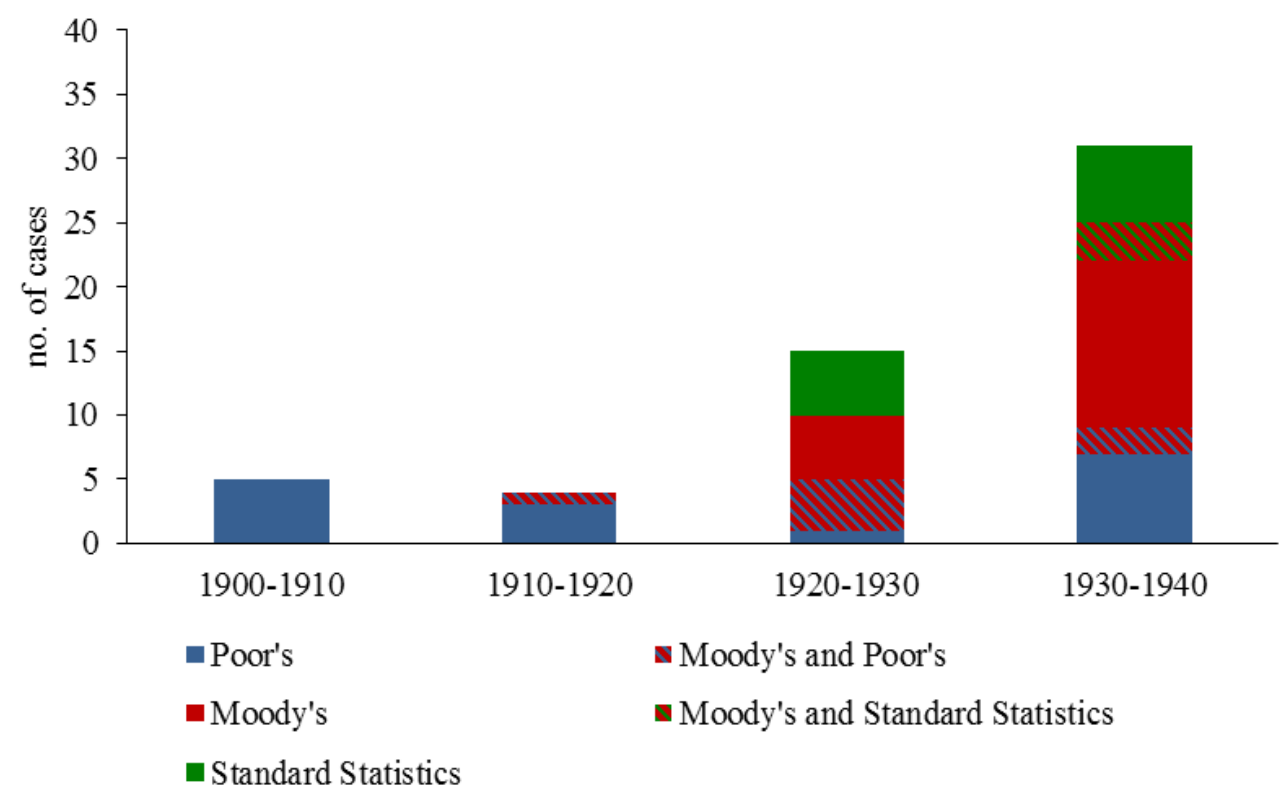

Source: Authors', from Westlaw

Evolution is summarized on Figure 1, which shows the rise in the incidence of court references to statistical organizations. ${ }^{10}$ Obviously, not only was the relevance of rating agencies for court decisions a phenomenon already present in the 1900s, but it can be argued that the take-off occurred in the 1920s, before rating became embedded in regulation.

Relative reliance on different organizations is another interesting matter to examine. In terms of incidence, Poor's was the leader till about 1920 when Moody's overtakes it. Standard Statistics is a latecomer, with the first quotation only in $1923 .{ }^{11}$ By and large, during the interwar Moody's can be described as the leader, with Standard Statistics gradually pulling out and catching up with Poor's. Poor's relative decline ended up with the merger between the

to court ruling regarding an action to rescind a contract "of a sale to plaintiff [Lawson] upon the ground of false representation made by the defendant Henry W. Poor, or Dennie M. Hare [an employ of Poor's]" where Henry W. Poor \& Co. was being sued for "inducing the plaintiff of such purchase." Willets v Poor et al., 141 A.D. 743, 126 N.Y.S. 926, (1910)).

${ }^{9}$ Previous research suggests that Fitch was the smaller in the group (Flandreau, Gaillard and Packer 2010).

${ }^{10}$ There were 11 cases involving several rating agencies. 7 cases involved Moody's and Poor's, 4 involved Moody's and Standard Statistics. No cases had reference to more than two rating agencies.

${ }^{11}$ This, as a matter of fact reflects the chronological "entry" of these various entities in the market for expertise. Poor's had an early presence as a reliable monitor of railroad securities. Moody's was started in 1900. Standard Statistics was only started in 1906. 
two agencies, in $1941 .^{12}$ Interestingly, this ranking coincides with what is known of the industry's league tables in terms of size, breadth of coverage, etc. ${ }^{13}$

\section{Relying on Rating Agencies}

The occasions for relying on the statistical organizations' output were varied. The "output" that features in the court reports included chiefly the manual (which described and rated the securities) but also, when it existed as a separate product, the price list. Our imperfect, but heuristic typology relies on the parties involved in the lawsuit. Four main categories are identified (by declining order of importance in our population of cases): (1) Taxman and corporate, (2) Trustee, (3) Brokers and/or stock sale fraud, (4) others ${ }^{14}$.

Tax cases include disputes between a taxpayer and the taxman (Commissioner of Internal Revenue) and the output of the statistical organizations is used for ascertaining the veracity of some data (price, worth etc.). For example, in Isaac L. Merrill v. Commissioner of Internal Revenue ${ }^{15}$ the petitioner, Isaac L. Miller, purchased Russian Government bonds "during the years from 1916 to 1918," bonds which the Soviet Government repudiated in February 1918. The bonds, however "were continuously quoted on the market at a low price and were sold through a broker at a price far below their cost to the petitioner" 16 and were hence viewed by him to fall under section 23(e) of the Revenue Act of 1928, which under certain circumstances allows for deductions from gross income. "The records of the Standard Statistics Co." ${ }^{, 17}$ were used to reconstruct the price evolution of the "bonds of the Russian Government (Fifth War Loan) 5 1/2's, 1926" ${ }^{18}$ and sort the valuation issue. To this type of lawsuits we may add "corporate" ones which typically pitted one company against the other and where the products of statistical organizations were used to ascertain the bare facts of the case. $^{19}$

\footnotetext{
${ }^{12}$ This is interesting as this conclusion matches observation by previous authors of the leadership of Moody's and gradually Standard Statistics, during the interwar.

${ }^{13}$ See e.g. Flandreau, Gaillard and Packer (2011).

${ }^{14}$ This leaves out a small number of cases. Union Electric Light \& Power Co. $v$ Snyder Estates et al., 65 F.2d 297 (1933); Commissioner of Banks v Chase Securities Corporation Brandegee v Same, 298 Mass. 285, 10 N.E.2d 472 (1937).

${ }^{15}$ Miller v Commissioner of Internal Revenue, 31 B.T.A. 530 (1934).

${ }^{16}$ Ibid.

${ }^{17} \mathrm{Ibid}$.

${ }^{18}$ Ibid.

${ }^{19}$ A characteristic example would be an anti-trust dispute such as Macon Grocery Co. et al v. Atlantic C.L.R. Co. et al. where the plaintiffs were wholesale dealers in groceries and the defendant a combination of railway companies grouped as 'Southeastern Freight Association' and accused by the grocers of being an illegal combination in restraint of interstate trade. In the instance, the court admitted as evidence "extracts from 'Poor's Manual of Railroads,' which it was testified [to be] an authoritative treatise on the subject." The extracts from Poor's were used "to show that the defendants were [indeed] grouped, (...) and that the lines of the defendants
} 
In "Trustee" cases, trustees feature as defendants in suits filed for mismanagement of entrusted money. In such cases, statistical organizations acted in capacity of instrument of evidence. This could be done indirectly, with the court relying on the material in one manual to demonstrate imprudence of the trustees. For example the 1902 Supreme Judicial Court of Massachusetts' Green vs. Crapo ${ }^{20}$ the “question whether, having money to invest, the trustees were justified in buying [certain company's] bonds" ${ }^{21}$ was examined under the light of Poor's Manual which showed that in " 1885 and 1886 " 22 the company "did not even pay its expenses." ${ }^{23}$ In other cases, reliance was not merely on the technical facts, which the court then used to make its own inference (a loss making company cannot be a sound investment, in the previous example), but on the organization's opinion itself. For example in a 1922 case, where the trustee is said to have benefited from discretionary powers, the audit judge turned to Moody's in order to assess the adequacy of a certain investment, made in 1915 at 98.12 but trading at 70 to 72 at the time of the audit: "In Moody's Manual for 1914, these [...] bonds are rated: 'Security, very high; Salability, good; net rating, 'A.' His manual gives the facts from which this conclusion is drawn. It appears from the testimony that bonds of this issue were brought out by Drexel \& Co. and Harrison \& Co., both banking houses of this city of the highest reputation, etc." 24

Brokers and/or stock sale fraud cases encompass suits against brokers or sellers of securities for false representations or erroneous reporting. An illustrative example is Henry v. Kopf in 1925 where the "defendant sought to sell to the plaintiff certain stock of the "Houdini Picture Corporation' [whose value predictably vanished!], and made therein certain material misrepresentations of fact to the plaintiff, and thereby fraudulently induced the plaintiff to purchase 125 shares of such stock at $\$ 10$ each; that said shares of stock were of no value." 25 Claiming misrepresentation on behalf of the broker (who had mentioned a dividend that could be as high as 50 percent) the plaintiff asked reimbursement. In the hearing before the Superior Court of New Haven County the plaintiff produced as witness one R.S. Bradley, a banker, who "testified that (...) he examined Moody's Current Rating Book as to the stock" ${ }^{26}$ and this is how he could see that the stock was worthless.

extended throughout all the territory" concerned. (Macon Grocery Co. et al v Atlantic C.L.R. Co. et al., 163 F. 738 (1908)).

${ }^{20}$ Green v Crapo, 181 Mass. 55, 62 N.E. 956 (1902).

21 Ibid.

${ }^{22}$ Ibid.

${ }^{23}$ Ibid.

${ }^{24}$ In re Detre's Estate, 273 Pa. 341, 117 A. 54, (1922).

${ }^{25}$ Henry v Kopf, 104 conn. 73, 131 A. 412 (1925).

${ }^{26}$ Ibid. 


\section{Moody’s Manuals as Farmer's Almanac}

From poring through these cases, it appears that courts used the products of statistical organizations as both reliable fact establishing outlets and providers of significant opinion. Indeed, the language of more than one court report construes the various products of early rating agencies as representative of "established opinion." Poor's Manual, was a "well known publication of railroad statistics" (1901), ${ }^{27}$ an "authority upon the amount and value of the stocks and bonds" (1907), ${ }^{28}$ was "testified an authoritative treatise on the subject [of Railroads]" (1908). ${ }^{29}$ Before buying securities, one orator consulted "Poor's Manual, and found therein a pretty full history" (1914). ${ }^{30}$ In a 1916 case, a testimony was received that the Chairman of the Board of Calumet \& Chicago Canal \& Dock Co, in order to investigate anomalies in balance-sheets, would "consult different financial magazines, such as the Economist and Poor's Manual." ${ }^{, 31}$ In another case decided in 1918, an investor "did not know whether [one road] would be a good investment. (...) He also testified that he knew that Poor's and Moody's Manuals were the best publications." ${ }^{, 32}$ In 1920 Moody's Manual is said to be describing a transaction "with exactness." 33 In a case from 1923, a witness testified that "he gathered his information concerning this stock from various publications, particularly from the list published by the Standard Statistics Company." ${ }^{34}$ Therefore, by the time the 1931 decision was taken, "market quotations and other financial data appearing (...) in the regularly published reports of business surveys, (...) Moody's Manual, Standard Statistics, and other like publications" 35 were thus acknowledged as "an authority upon the amount and value of the stocks and bonds of (...) corporations in this country [the United States.] ${ }^{, 36}$ Thus it is that, while the 1930s did see an inflation of similar statements, court recognition of the agencies as valuable providers of information was a significantly older phenomenon.

\footnotetext{
${ }^{27}$ Chicago, R.I. \& P. RY. Co. v Hannibal \& St. J. R. Co., 110 F. 599 (1901).

${ }^{28}$ Western Union Telegraph Co. v Dodge County, 80 Neb. 18, 113 N.W. 805 (1907).

${ }^{29}$ Macon Grocery Co. et al v Atlantic C.L.R. Co. et al., 163 F. 738 (1908).

${ }^{30}$ Smythe v Central Vermont Ry. Co., 88 Vt. 59, 90 A. 901 (1914).

${ }^{31}$ Calumet \& Chicago Canal \& Dock Co. v Stuckart, 275 Ill. 253, 113 N.E. 894 (1916).

${ }^{32}$ In re McDowell et al., 102 Misc. 275, 169 N.Y.S. 853 (1918).

${ }^{33}$ Eisner v Macomber, 252 U.S. 189, 40 S.Ct. 189 (1920).

${ }^{34}$ Brown v. Gray \& Wilmerding, 256 S.W. 977 (1923).

${ }^{35}$ Mount Vernon Trust Company, Emily F. Whitmore v Commissioner of Internal Revenue., 1938 WL 81006 (B.T.A.) (1938).

${ }^{36}$ Evidence on the capitalization of companies, such as The Brown-Lipe Gear and Continental Motors Corporation in the taxpayer's action of Brockway Motor Corporation v. City of New York from 1931, would thus be presented “according to Poor's, [Moody's or Standard Statistics'] manual[s]," (Brockway Motor Corporation $v$ City of New York et al., 145 Misc. 693, 261 N.Y.S. 725 (1931)) while for presentation of the pricing of bonds the "publications were offered and received in evidence" (Dubuque Fire \& Marine Insurance Company v Commissioner of Internal Revenue, 1935 WL 6479 (B.T.A.) (1935)).
} 
This recognition however may be construed in a rather modest way as the admission by courts of documents thought to be transparent to brute fact. This would have been as opposed to their exclusion of agencies' output as "hearsay" a position, which would have required $\mathrm{Mr}$ Moody or some other to come in person and testify. This interpretation may be supported by two cases where lower courts refused to admit agencies' output (presumably because they were hearsay). In Trakas v. Cokins (1922) ${ }^{37}$ a broker sought to disprove his wrongdoing by showing how the security was described by Moody's Manual but was prevented by a lower court from doing it, but the Appellate Court of Illinois First district ruled that the lower court's decision to "refuse to permit defendant to testify that [Moody's Manual of Railways and Corporation Securities of 1918] was a standard manual for 1918,"38 was error and found in favor of the broker (appellant), asking for a retrial. ${ }^{39}$ A few years later in Henry v. Kopf (1925), ${ }^{40}$ the Supreme Court of Errors of Connecticut found that a Court in New Haven had erred in refusing evidence about Moody's manual. When asked "if [Moody's] was a 'recognized authority', upon objection of the question" 41 the witness did not answer. The lower court had also ruled that if the Moody's manual had been produced it would not admit it. In ordering the retrial, the Supreme Court pointed to the exclusion of evidence. In its decision it commented that the reports such as that of Moody's, "based upon a general survey of the whole market, and (...) constantly (...) acted upon by dealers" are "far more satisfactory and reliable than individual entries, or individual sales or inquiries" and concluded that "courts would justly be the subject of ridicule, if they should deliberately shut their eyes to the sources of information which the rest of the world relies upon, and demand evidence of a less certain and satisfactory character." 42 According to this interpretation, the manuals entered into courts the way the Farmer's Almanac did: as a natural and legitimate instrument to tell the financial weather - an instrument which courts would have been ridiculous not to use liberally. There is no doubt that this interpretation is particularly plausible when the most "technical" output (such as pricing) were used. In such cases, the agencies were not that different from the Farmer's Almanac, telling people whether it had been a warm or a cool day.

\footnotetext{
${ }^{37}$ Trakas v Cokins, trading as Cokins \& Company, 224 Ill.App. 327, 1922 WL 22067 (Ill.App. 1 Dist.) (1922).

${ }^{38}$ Ibid.

${ }^{39}$ Ibid.

${ }^{40}$ Henry v Kopf, 104 Conn. 73, 131 A. 412 (1925)

${ }^{41}$ Ibid.

${ }^{42}$ Ibid. (emphasis added).
} 


\section{The Legal License}

On the other hand, the language found in a number of cases (especially those involving brokers or trustees) reveals a pattern, which invites an alternative interpretation of courts' reliance on ratings agencies - one whereby the enforcement by courts of rating opinions conferred the agencies a genuine legal license. Indeed, if one looks at the language used in courts when the legitimacy of the agencies' output is discussed, one finds that, in all cases where motivations for the use of an agency's manual are stated, no direct endorsement by the court is offered but instead, it is said that the manuals or agency's output represent a kind of benchmark conventionally accepted by the banking and security's trading profession.

To quote just a few excerpts in a long list of supporting statements: In 1920 a discussion of the contents of one Moody's manual is followed by the inference that through the statements made in the manual certain properties of the security become apparent to "financiers and investors." ${ }^{43}$ In Henry v. Kopf just discussed, the higher court stated that in so far as the expert called by plaintiff "was found to be a dealer in stocks and acquainted with the market value of stocks," 44 "he was a proper witness as to what market reports are accredited as trustworthy." ${ }^{45}$ In 1927, a testimony is received "that such books as the publications of 'Standard Statistics' are used and relied upon in the banking and security trading world." ${ }^{46}$ In a 1930 case, it is said that the vice president's of Stanley Corporation duties included "the reading over of Moody's and Standard Statistics investment service. ${ }^{, 47}$ In a 1935 case, it is declared that "all of the banks admittedly subscribed" to "Moody's and other statistical manuals." ${ }^{48}$ In other words the point is that the courts were striving to rely on the financial industry's own recognized standards. This amounts to the sanctioning of a form of selfregulation (a mechanism that is substantially similar to the mechanism that has been said to be at the heart of the subprime crisis).

We suggest interpreting this ruling strategy as stemming from the "prudent man principle", which, according to previous writers, was forged in the US by Harvard College v. Amory (1830). ${ }^{49}$ In this landmark case, it was decided that Trustees should "observe how men of prudence manage their own affairs, not in regard to speculation, but in regard to the permanent disposition of their funds, considering the probable income, as well as the probable

\footnotetext{
${ }^{43}$ Eisner v Macomber, 252 U.S. 189, 40 S.Ct. 189 (1920).

44 Ibid.

${ }^{45}$ Ibid.

${ }^{46}$ Commercial Trust Co., v Commissioner of Internal Revenue, 8 B.T.A. 1138 (1927).

${ }^{47}$ Stanley Securities Co. v United States, 69 Ct.Cl. 271, 38 F.2d 907 (1930).

${ }^{48}$ Kelly v Central Hanover Bank \& Trust Co. et al. Bigelow v Kelly et al., 11 F.Supp. 497 (1935).

${ }^{49}$ Harvard College v Amory Pick, Harvard College v Amory Pick, 26 Mass. 446(1830)
} 
safety of the capital to be invested." ${ }^{50}$ As J.H. Langbein put it, a result of Harvard College v. Amory was that "the standard of prudent investing was the standard of industry practice."51 Of course, defining the industry practice must have been a challenge for courts, which would have to weigh one entry against the other. Alternatively, if the community had grown its own handbooks, then it would be much easier to identify "speculative" investments. Significantly, this expression comes up quite often in our database of cases quoting the authority of statistical agencies, as opposite to prudent, or the case being "conservative" or "high rating" investment (thus belying attempts to find in the 1931 OCC ruling the origin of the investment v. speculative grade wording). ${ }^{52}$

In re MacDowell et al. has a clear statement of the mechanism at work. There, one of the trustees testified that "he knew that Poor's and Moody's Manuals are the best publications, but he could not tell whether he consulted them before or after the purchase of the bonds" prompting the judge's to state that "the trustees did not employ such vigilance, sagacity, diligence, and prudence as, in general, prudent men of discretion and intelligence employ in like matters of their own affairs. ${ }^{53}$

In summary, reference to rating came up in a number of situations, as a valid test to decide whether agents had behaved in a prudent manner. It is not surprising therefore that we came across the agencies in cases involving trustees' investments, because trustees are supposed to manage prudently the monies which they have received from others or in cases involving banks since banks, as emphasized by Brandeis before WWI, were likewise dealing with "other people's money."

\footnotetext{
${ }^{50}$ Langbein, John H., 1996. The uniform prudent investor Act and the Future of Trust Investing. Iowa Law Review, 81, p. $644 \mathrm{ff}$.

${ }^{51}$ This differed from the use of legal lists as was done in Britain, where Chancellors developed restricted lists of "proper" trust investments. Initially limited to first mortgages and (British) government bonds, the list was expanded in 1859 to East India Company stock (after the British Government took over India thus making East India a British stock), and subsequently to Colonial Bonds (Colonial Stock Act of 1900). Following decolonization, the statute was amended in 1961 to allow trustees to invest in equities.

${ }^{52}$ For instance an opinion from the Orphan Court, quoted in In re Detre's Estate, 273 Pa. 341, 117 A. 54, (1922), stated that some Georgia Railway bonds "while not of the highest grade, were such as were purchased by conservative investors, and considering that this trust was not limited to legal investments, and the beneficiaries were anxious to get a return of 5 per cent., were a proper in- vestment for this estate. Had interest rates remained the same these bonds would probably be convertible today without loss", etc. On the use of "investment grade" in a fairly early time, one can quote In re Winburn's Will, 140 Misc. 18, 249 N.Y.S. 758 (1931) where it is said: "The AA rating is a high investment rating and given to few common stocks. It indicates a dominant position in the industry, tremendous earning power, and ample cash resources. The rating of A comes in the investment group, but to a lesser degree. B is the rating applied to the stocks of companies, which give the expectation of a regular dividend payment. BA is given to a common stock when the company has shown definite progress in its line, has built up reasonable equities for its securities, and has shown a reasonable ability to continue dividend payments. There is a distinction between seasoned securities of the character here involved and investments in speculative securities, etc." Contrast with Fons (2004) who claims: "Thus, it appears that the term investment grade arose through market convention and then regulatory appropriation."

${ }_{53}$ In re McDowell et al. 102 Misc. 275, 169 N.Y.S. 853, (1918).
} 


\section{Legal License and Conflicts of Interest: Evidence from Moody’ Memoirs}

But if this latter interpretation is accepted, then we are dealing with a case where courts accepted the products of the agencies without reference to what they thought of them. It is possible or likely that they thought highly of them (this is suggested for instance by an instance where Justice Brandeis quotes John Moody's Truth on Trusts, not a manual or rating book, although certainly a reference volume) ${ }^{54}$ But what exactly the courts thought is irrelevant. In the above quotes, we are always dealing with the claim that ratings are routinely used and processed by myriad financiers and thus somehow "aggregate" the financial industry standards. Such standards can then be used to gauge an individual's behavior.

Now, suppose that there existed a loophole in the way ratings were being produced (too high a grade for a certain type of product that would be really "crap"). Then intermediaries would have been tempted to nonetheless distribute such "crap" as they would not have faced ex post liability - a mechanism similar to the posited logic of the "regulatory license".

Indirect evidence that is relevant to this view can be gleaned from John Moody's own memoir (The long road home). This book does provide a discussion of two interesting episodes taking place in the early $20^{\text {th }}$ century. ${ }^{55}$ They are interesting, because they underscore the existence of an early form of modern conflicts of interest.

In one episode, Moody would have been contacted by the lawyers of one prominent corporation (as one of the "largest industrial corporations in the United States"), which had hired the "best legal talent in America" to fight what appears to have been an anti-trust lawsuit. They invited him in a room where he was surrounded by a "dozen lawyers" who wanted him to "certify the correctness of the figures" 56 produced by the said company. The figures intended to show that other firms that had not been sued "had been even more guilty of gouging the public." As Moody states, "the certification of an outsider would of course carry more weight with the court than any unsupported statements presented by the defendant itself." 57

In the other instance Moody was approached by representatives of the "public interest" or buy-side. The context was that of the public inquiry into the "Money Trust" and he claims that individuals who pushed the inquiry such as Senator Robert M. LaFollette and also the

\footnotetext{
${ }^{54}$ Liggett Co. et al .v Lee, et al., 288 U.S. 517, 53 S.Ct. 481 (1933). In the same case, Brandeis also referred to the 1932 edition of Moody's Industrial Securities.

${ }^{55}$ This was when, after a successful start, John Moody had been bankrupted by investments made before the 1907 crisis. At that point, Moody had sold out his previous franchise and restarted a new business and manual, which he meant to be more sophisticate than the previous one (this was when he began to combine his reports with the supply of grades).

${ }^{56}$ Moody (1935), 156-8 (emphasis added).

${ }^{57}$ Moody (1935), 156-8
} 
brothers Gifford and Amos Pinchot and Louis Brandeis felt that Moody would have "looked to [him] in 1910 or 1911 to expose the alleged stupendous 'money-trust', which the Pujo committee in Congress attempted to chase."

As Moody confesses, in both cases the "temptation" was there, especially in the anti-trust case where lawyers for the big firm would have declared that they would "make it worth [his] while to do this." Pointing to the reasons why, after playing with the idea for "one afternoon," he decided against it, he suggests moral imperatives ("I was struggling to preserve my honor and integrity in the business world") and long run unsustainability ("Once started, there would be no stoppage; I would continue to follow this downward path. I might grow quickly rich, as there would be a myriad of such opportunities ahead, I well knew. But I also knew that I would have to continue to live with myself. And I turned it down.") ${ }^{59}$

The examples may not be perfect - since they stage Moody himself rather than his manuals. On the other hand, with such a highly personalized branding as existed in early statistical agencies, Moody the expert and Moody the provider of grades were the two sides of the same coin. And the point we make is that the kind of temptation John Moody acknowledges having experienced is very similar in essence to its modern avatar (Moody's and the subprime). We underscore that, early on, the agencies controlled a veto point, in delegation of the US court system.

\section{Legal License and Conflicts of Interest: Evidence from Moody’ Balance Sheet}

A license is valuable. If agencies enjoyed a legal license, then one would expect them to be tremendously profitable before the interwar market crash. Indeed, all the intermediaries who were concerned about demonstrating good behavior (banks, trustees, etc.) during the phase of euphoria in the 1920s, would purchase the manuals (so that would be able to tell the judges they did) and this would boost Moody's profits. In other words, the strong pro-cyclicality that has been observed for the profitability of rating agencies during the 2000s should be observed as well during the interwar. Many observers of the modern crash have faulted the "issuer pays model", suggesting that the charging of sellers rather than buyers can have deleterious effects. But our reasoning implies that the charging of buyers, or rather "trustees" or delegated agents for the investors is likely to have similar consequences.

\footnotetext{
${ }^{58}$ Moody (1935), 161-2. See above Liggett Co. et al. v Lee, et al., 288 U.S. 517, 53 S.Ct. 481 (1933), for an illustration of Brandeis interest for Moody's work.

${ }^{59}$ Moody's (1935), p. 158.
} 
There is a dearth of statistical information on the financial performance of the agencies during the interwar, largely because they were private firms and have no open records. However, Moody's went public in late 1928 (probably not incidentally as this was a year of financial euphoria and booming profits) and as a result of disclosure rules for NYSE securities, some data for Moody's from 1929 to 1938 is available at Harvard Business School's Baker Library (and since Moody's was the market leader this is valuable proof). This material enabled us to construct Figure 2, which shows the nominal operating income and Moody's stock price (Down Jones Industrial-Adjusted) ${ }^{60}$ The result is striking: The behavior of both statistics was strongly pro-cyclical. Mirroring movement in sales, Moody's stock price plummeted following the market crash of 1929, more than the Dow Jones, and kept falling until 1933. Moody's stock price started recovering after 1934, thus essentially amplifying stock market trends.

Figure 2. Moody's Stock Price (DJ adjusted) and Pre-Tax Net Operating Income (nominal)

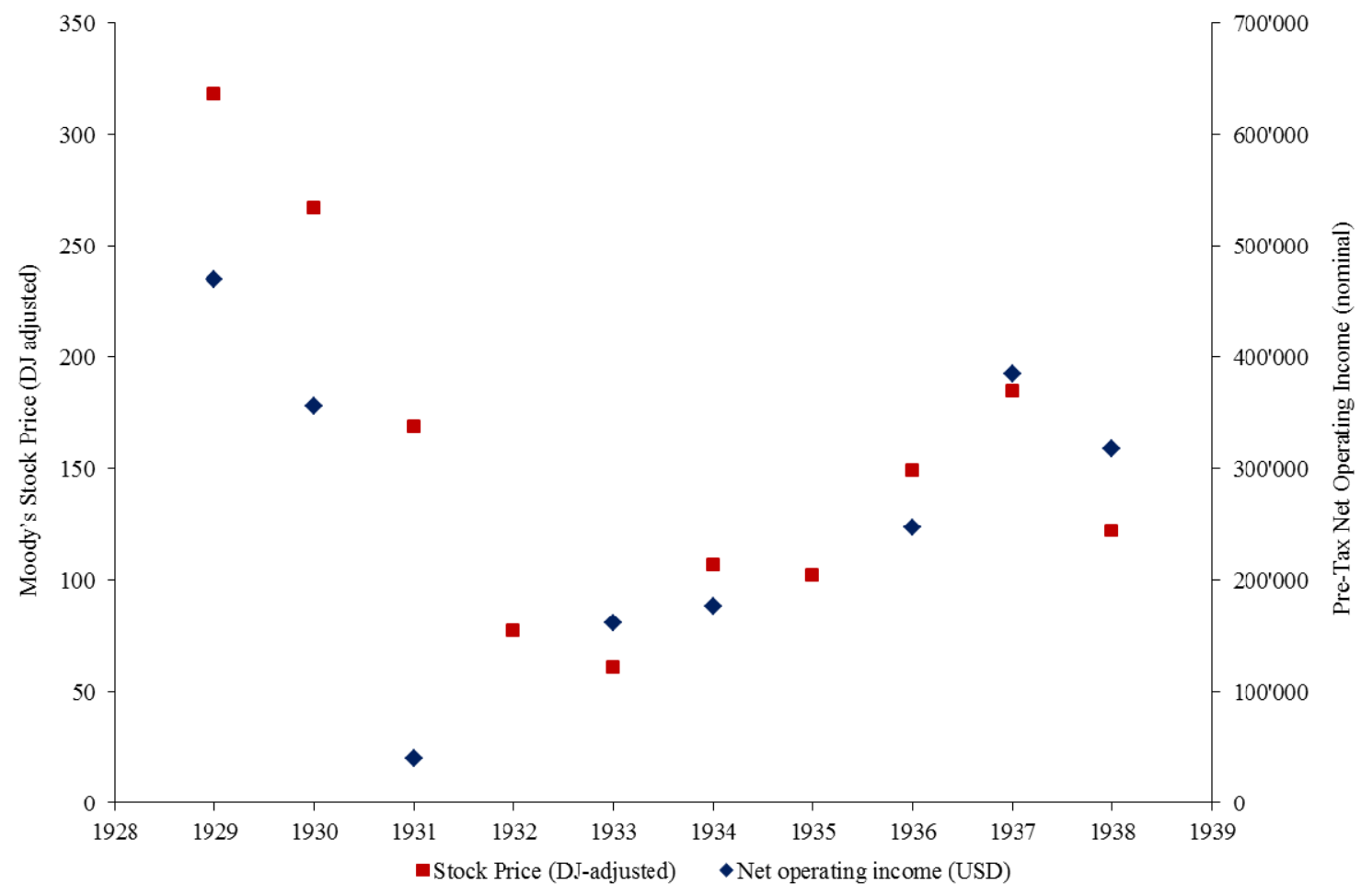

\footnotetext{
${ }^{60}$ Moody's was the only stock market listed agency (it had been listed in 1928), explaining why some details are available. We are grateful to Norbert Gaillard for assistance with the data.
} 
Source: Authors' from Wall Street Journal and Baker Library. Net operating income (pre-tax is from Moody's returns in HBL; Fiscal year ends September). Stock Prices for Moody's preferred stocks (annual averages) are from Moody's own annual reports, and adjusted using the DJ Industrial Average (Moody's listed itself in its own manual along with industrial companies). Returns for 1932 and 1935 are missing.

While we do not discount the possibility of this having been driven by other factors, we are struck by the fact that conventional arguments about regulatory license and the great subprime disaster appear to neglect the fact that the existence of agencies' conflicts of interest may not be new. This paper suggests one reason for this: Namely, that before the regulatory license there was a legal license. ${ }^{61}$ This urges us to both scapegoat less the rating agencies' regulatory license when we observe it and to be less comfortable when we don't.

\section{Regulatory and Legal License in Historical Perspective}

Upon reflection, this finding may not be so surprising. An important tradition of scholarship in law and economics has discussed the reasons for choice between common law to regulatory law as proper instruments to enforce rights (Shavell 1984, Posner 1998). Other scholars have discussed aspects of the historical transition from common law to regulatory law, which they have associated with the Progressive and/or New Deal Era (Landis 1938, Glaeser and Shleifer 2003).

Our evidence suggests a similar process in the realm of ratings. Rather than regulators suddenly reaching out for (ill-conceived) ratings we have emphasized the existence of a seamless transition between court arbitration and regulatory arrangements. A good illustration of this transition is provided the way early state statutes adopted after 1911 and ostensibly designed to protect investors against fraudulent schemes ended up relying on courts. "Blue Sky Laws" (as they were known, since fraudulent schemes included the sale of real estate "in the blue sky") ${ }^{62}$ were intended to limit "speculative" investments. Some "safe" investments (such as state bonds) were explicitly listed but in other cases statutes included more ambiguous language. In Trakas v. Cokins (1922) the issue was a section of the State of Illinois' Blue Sky Law, which mentioned that among the securities that could be lawfully sold in Illinois, were "securities listed in a standard manual or in manuals approved by the

\footnotetext{
${ }^{61}$ Incidentally, the Comptroller of the Currency "pro-rating agencies" move in 1931 does not seem to have been successful at preventing the decline of Moody's indicators at least over the short run. If statistical agencies received a new license in the 1930s, this should have shown up in their operating income, stock price or both. Presumably this is because their new relevance would have consolidated their market power, and enabled them to capture a regulatory rent. According to this line of reasoning, the agencies' performance during the Great Depression should have been somewhat anti-cyclical, because the new regulation, occurring in 1931, would have acted as a buffer. Obviously, our evidence only indicts the most simplistic interpretation of the regulatory license view, which nobody to our knowledge ever upheld.

${ }^{62}$ Macey and Miller, “Origins of blue sky laws,” Texas Law Review, 70 No. 2 (1991).
} 
Secretary of the State of Illinois." As we saw, the defendant, a broker, had been prevented by a lower court "to testify that [Moody's Manual] was a standard manual of 1918 " and the higher court found this was error so that eventually, the Illinois Blue Sky Law was relying on the agencies. In effect, however, the regulator had waited for the courts to decide what she had meant when she had mentioned "standard manuals". The authors of state statutes must have meant Moody's, Poor's or Standard Statistics, courts found. ${ }^{63}$

From this vantage point, the Comptroller of the Currency was fully "justified" when he issued his 1931 ruling (In this sense his own liability was addressed by the practice of the US judiciary). Some may emphasize that there was still a discontinuity after 1931 because regulators can do things far more abstract and dangerous than common law courts. One is, according to the regulatory license view, the granting of a privilege that is not "bound" by performance. But our evidence suggests that this is probably too optimistic a view. The delegation that US courts gave Moody's and others in the first half of the century was not merely limited to ascertaining facts at hands. They recognized the grades and financial opinions as relevant benchmark of prudent practice. But such opinions were nothing but the "wisdom of the industry" and we fail to see the fundamental difference with today. What if the industry at large fails, which obviously has been the case in the subprime crisis and arguably was the case in the interwar crisis.

In fact, when discussing the modern failure of rating agencies few realize that it had a precedent in the agencies" "inability" to predict the 1931 bond debacle (Although this interwar "failure" has been emphasized previously for different parts of the bond market: Braddock 1958, Flandreau et al. 2011). This is too short a paper to demonstrate that the legal license contributed to the interwar debacle. But we have provided some evidence supporting the view that if anyone believes in the story that the regulatory license caused the subprime crisis, then she should be prepared to consider that the legal license was a significant element of the interwar problems and as a result, that there is something deeper and more "pernicious" in our inextinguishable thirst for rating.

\section{Conclusions}

\footnotetext{
${ }^{63}$ Trakas v Cokins, trading as Cokins \& Company, 224 Ill.App. 327, 1922 WL 22067 (Ill.App. 1 Dist.) (1922). Another interesting case showing the early reliance by regulators on rating agencies is Commissioner of Banks $v$ Chase Securities Corporation Brandegee v Same, 298 Mass. 285, 10 N.E.2d 472 (1937) which quotes the testimony of an inspector of the Department [the Massachusetts Commissioner of Banks] to show that in 1928, 1929 and 1930 it was a practice of the Commission to accept information from [Moody's and Poor's Manual] in lieu of statements or questionnaires."
} 
This paper has offered some background to the "landmark" regulatory decisions taken in 1931 and during the following years and which are said to have ingrained rating agencies into US financial capitalism. This view of an epoch making transition in 1931 is held by both supporters and critics of the rating agencies. It is associated with the concept of "regulatory license" emphasized by Frank Partnoy.

The alternative we articulated in this paper is that, by the time the 1931 decision was taken, a license the statistical organizations already had. It stemmed from the recognition and enforcement by courts of norms of prudence construed as emanating from the financial industry and of which the rating agencies were experts and arbiters. The decision in 1931, in our alternative scenario, would not be as significant as suggested by the regulatory license view. In other words, what we are arguing here, is that courts granted the agencies a property right over the ascertaining of financial behavior, and regulators only took note of this property right.

According to this alternative, the 1930s indeed witnessed a dramatic shift in the replacement of court litigation (and states' Blue Sky Laws) by federal regulation. But there was substantial continuity as to the tool on which all these supervisory arrangements relied to judge financial behavior, and ascertain "investment grade." Owing to the courts' reliance on the expertise of agencies, the organizations were already entrenched in the fabric of United States capital markets. Before the statistical organizations became "nationally recognized" by Federal supervisors, they had in fact been "recognized nationally" by US judges and this generated tensions not unlike those that have been discovered lately.

\section{References:}

Braddock, Hickman, W. 1958, Corporate Bond Quality and Investor Experience, Princeton University Press.

Flandreau, Marc \& Gaillard, Norbert \& Packer, Frank, 2011. "To err is human: US rating agencies and the interwar foreign government debt crisis," European Review of Economic History, Cambridge University Press, vol. 15(03), pages 495-538, December.

Fons, Jerome, 2004. "Tracing the Origins of 'Investment Grade”, Moody's Investors Service.

Glaeser, E. L. and A. Shleifer, 2003, "The rise of the regulatory state", Journal of Economic Literature, Vol XLI, pp. 401-25.

Harold, Gilbert, 1938, Bond ratings as investment guide, New York: Ronald Press. 
Landis, James M., 1938, The Administrative Process, New Haven: Yale University Press.

Langbein, John H., 1996. "The uniform prudent investor Act and the Future of Trust Investing”. Iowa Law Review, 81, pp. 641-69.

Macey, Jonathan, and Geoffrey Miller, 1991, "Origin of the Blue Sky Laws", Texas Law Review, 70, 2, 348-97.

Moody, John. 1935. The long road home: An autobiography, New York: The Macmillan Company.

Partnoy, Frank, 1999. “The Siskel and Ebert of Financial Markets?: Two Thumbs Down for the Credit Rating Agencies”. Washington University Law Quarterly, 77, pp. 619-712, at 622.

Partnoy, Frank. 2006. "How and Why Credit Rating Agencies Are Not Like Other Gatekeepers”, in Yasuyuki Fuchita, and Robert E. Litan (eds.), Financial Gatekeepers: Can They Protect Investors?, Brookings Institution Press and the Nomura Institute of Capital Markets Research.

Posner, Richard, 1998, Economic Analysis of the Law, $5^{\text {th }}$ ed. Boston: Little Brown.

Shavell, 1984, "A model of optimal use of liability and safety regulations", Rand Journal of Economics, 15:2, pp. 271-80.

Woodruff, George P. 1935. "Legal and investment standards of trustees". Fordham Law Review, 4(3), pp. 391-415.

\section{Legal Case References:}

Banks v Chase Securities Corporation Brandegee v Same, 298 Mass. 285, 10 N.E.2d 472 (1937).

Brockway Motor Corporation v City of New York et al., 145 Misc. 693, 261 N.Y.S. 725 (1931).

Brown v. Gray \& Wilmerding, 256 S.W. 977 (1923).

Calumet \& Chicago Canal \& Dock Co. v Stuckart, 275 Ill. 253, 113 N.E. 894 (1916).

Chicago, R.I. \& P. RY. Co. v Hannibal \& St. J. R. Co., 110 F. 599 (1901).

Commercial Trust Co., v Commissioner of Internal Revenue, 8 B.T.A. 1138 (1927).

Commissioner of Banks v Chase Securities Corporation Brandegee v Same, 298 Mass. 285, 10 N.E.2d 472 (1937).

Dubuque Fire \& Marine Insurance Company v Commissioner of Internal Revenue, 1935 WL 6479 (B.T.A.) (1935). 
Eisner v Macomber, 252 U.S. 189, 40 S.Ct. 189 (1920).

Green v Crapo, 181 Mass. 55, 62 N.E. 956 (1902).

Harvard College v Amory Pick, Harvard College v Amory Pick, 26 Mass. 446(1830)

Henry v Kopf, 104 Conn. 73, 131 A. 412 (1925).

In re Detre’s Estate, 273 Pa. 341, 117 A. 54, (1922).

In re McDowell et al. 102 Misc. 275, 169 N.Y.S. 853, (1918).

In re Winburn's Will, 140 Misc. 18, 249 N.Y.S. 758 (1931).

Kelly v Central Hanover Bank \& Trust Co. et al. Bigelow v Kelly et al., 11 F.Supp. 497 (1935).

Lawson v State, 161 Miss. 719, 138 So. 361 (1931).

Liggett Co. et al. v Lee, et al., 288 U.S. 517, 53 S.Ct. 481 (1933).

Macon Grocery Co. et al v Atlantic C.L.R. Co. et al., 163 F. 738 (1908).

Miller v Commissioner of Internal Revenue, 31 B.T.A. 530 (1934).

Mount Vernon Trust Company, Emily F. Whitmore v Commissioner of Internal Revenue., 1938 WL 81006 (B.T.A.) (1938).

New State Ice Co. v Liebmann, 285 U.S. 262, 52 S.Ct. 371 (1932).

Stanley Securities Co. v United States, 69 Ct.Cl. 271, 38 F.2d 907 (1930).

Smythe v Central Vermont Ry. Co., 88 Vt. 59, 90 A. 901 (1914).

Trakas v Cokins, trading as Cokins \& Company, 224 Ill.App. 327, 1922 WL 22067 (Ill.App. 1 Dist.) (1922).

Union Electric Light \& Power Co. v Snyder Estates et al., 65 F.2d 297 (1933).

Western Union Telegraph Co. v Dodge County, 80 Neb. 18, 113 N.W. 805 (1907).

Willets v Poor et al., 141 A.D. 743, 126 N.Y.S. 926, (1910). 


\section{Appendix}

Three individual searches were performed on Westlaw, seeking to find hits corresponding to quotations of a rating agency in the case proceedings for the years 1900-1940. For the remaining three the searches always followed the same blueprint namely:

Your Search: "search name for a given rating agency" \& da(aft 1900 \& bef 1940)

Client Identifier: WLIACADEMIC

Database: $\quad$ ALLCASES

The search names for each of the rating agencies were: "Moody's", "Poor's", and "Standard Statistics". For example, in the case of Moody's the following query was implemented:

Your Search: "Moody's” \& da(aft 1900 \& bef 1940)

Client Identifier: WLIACADEMIC

Database: $\quad$ ALLCASES

Next, the cases were each screened for the correctness of the reference.

For the individual rating agencies the number of valid and unrelated cases is as follows:

Figure A.1. Number of unrelated vs. valid cases by rating agency

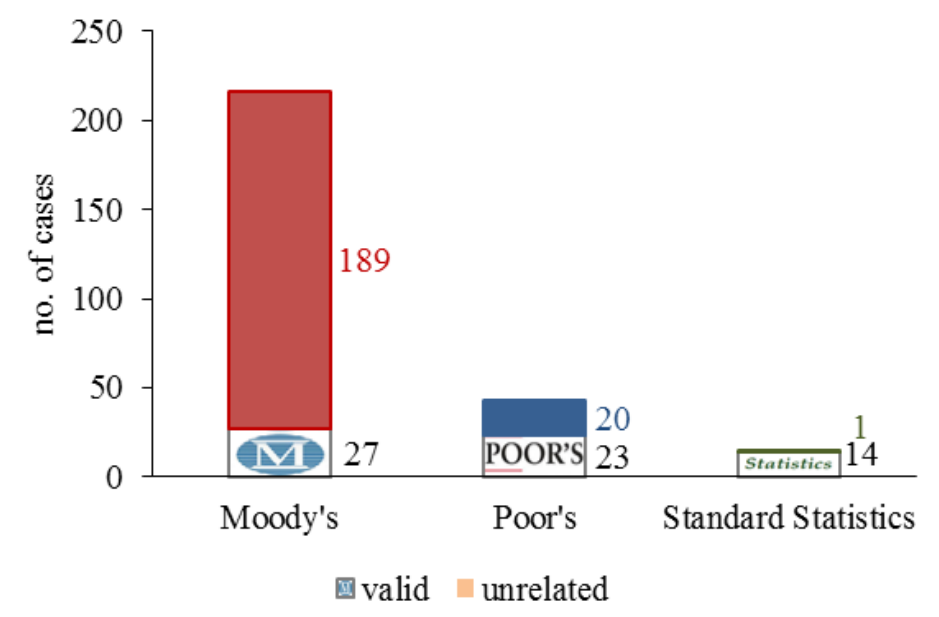

Source: Authors', from Westlaw 
Clearly, out of the three rating agencies, the case of Moody's was the most problematic, with the search query yielding the largest number of unrelated cases (both in absolute and relative terms. $)^{64}$ Whilst for Moody's and Poor's rating agencies only $12.5 \%$ and $53.5 \%$ of the cases remain after dropping the unrelated ones respectively, for Standard Statistics this is $93.3 \%$, with the only case dropped being a reference to a preceding hearing of Standard Statistics. Amusingly, in view of the discussion by John Moody, of Sen. LaFollette's passion for rating, this was the hearing of Mr. L. H. Sloan, vice president of the Standard Statistics Company, in the LaFollette subcommittee of the Senate Committee on Manufactures. ${ }^{65}$

Furthermore, all cases were assigned the following attributes: ID, agency ID, agency code, idd, case citation, name, and rating agency.

Table A.1

\begin{tabular}{ll}
\hline \hline attribute & definition \\
ID & case ID \\
agency ID & agency ID (restarts from 1 for every rating agency) \\
agency code & "S" for Standard Statistics, "P" for Poor's, "M" for Moody's \\
idd & combination of agency ID and agency code ("ID"- "agency code" "agency ID") \\
case citation & citation number (bibliographic reference number, as given by Westlaw) \\
name & case name \\
rating agency & rating agency name: "Standard Statistics", "Poor's", "Moody's" \\
\hline \hline
\end{tabular}

Apart from the unrelated cases, all the remaining ones were furthermore coded: Table A.2

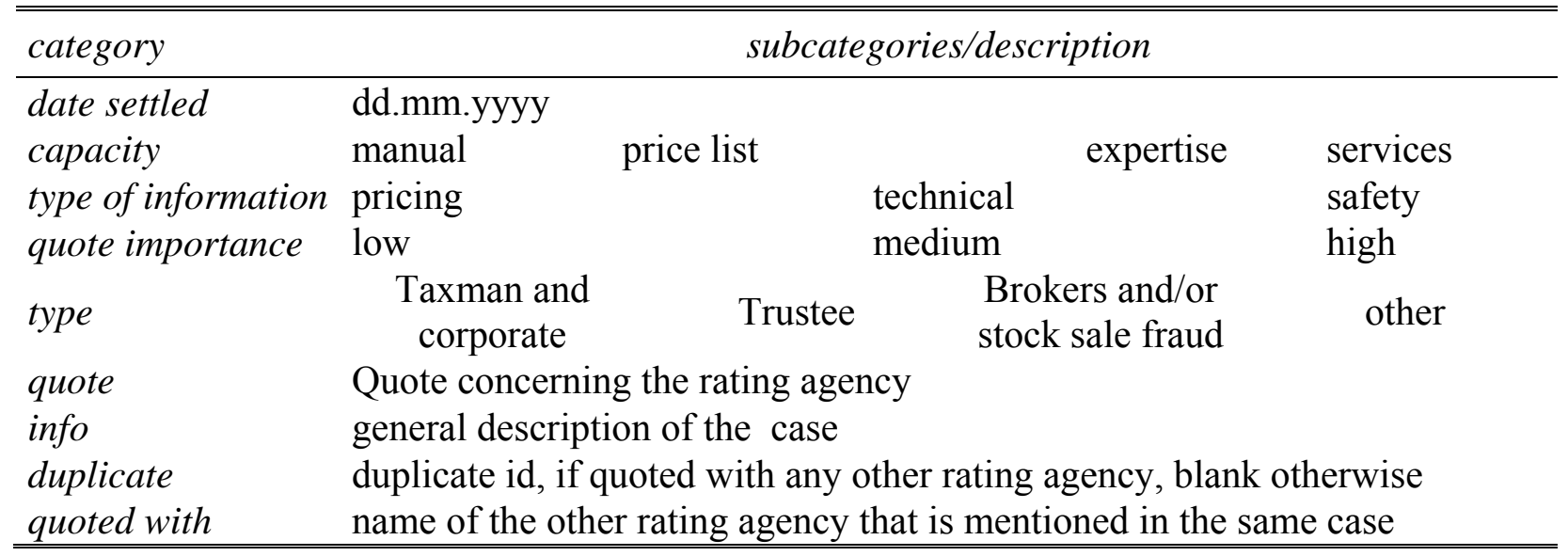

\footnotetext{
${ }^{64}$ Amongst others, some commonly appearing unrelated Moody's cases are the Moody's Heirs, Moody's Crown or Justice Moody.

${ }^{65}$ The respective case is the New State Ice Co. v Liebmann, from the $21^{\text {st }}$ of March, 1932, where the search hit appears in reference to a case quoted: "FN49 See Hearings before the LaFollette subcommittee of the Senate Committee on Manufactures, Seventy-Second Congress, First Session, on Senate Bill 6215 (71st Congress), to establish a National Economic Council, Parts 1 and 2 (October 22 to December 19, 1931), particularly the testimony of Dr. E. A. Goldenweiser, director of research and statistics of the Federal Reserve Board, of Mr. L. H. Sloan, vice president of the Standard Statistics Company, and of Miss Frances Perkins, Industrial Commissioner of the state of New York, pp. 3-150; 'When We Choose to Plan,' Graphic Survey, March 1, 1932. See, also, Hearings on December 28, 1931-January 9, 1932, the La Follette Costigan Bills, Senate Bills Nos. 174, 262, and 3045 (72d Congress)." New State Ice Co. v Liebmann, 285 U.S. 262, 52 S.Ct. 371 (1932).
} 
Cases were also examined for co-quotations. Namely whenever a case quoted more than one rating agency simultaneously a note was taken. As can be seen from the table which follows, no cases, had reference to more than 2 rating agencies.

Table A.3

name rating agencies quoted

\begin{tabular}{|c|c|}
\hline In re McDowell et al., 102 Misc. 275 , & Moody's \& Poor's \\
\hline Couznes v Commissioner of Internal Revenue, 11 B.T.A. 1040 (1928) & Moody's \& Poor's \\
\hline $\begin{array}{l}\text { irst Wisconsin Trust. v. Schultz et al., } 221 \text { Wis. 472, } 266 \text { N.W. } \\
\text { 1936) }\end{array}$ & Moody's \& Standard Statistics \\
\hline $\begin{array}{l}\text { Internal Revenue Collector, v. Macomber, } 252 \text { U.S. 189, } 40 \text { S.Ct. } 189 \\
\text { (1920) }\end{array}$ & Moody's \& Poor's \\
\hline $\begin{array}{l}\text { brams v Love et al., } 254 \text { Ill.App. 428, } 1929 \text { WL } 28356 \text { (Ill.App. } 2 \\
\text { ist.) (1929) }\end{array}$ & Moody's \& Poor's \\
\hline $\begin{array}{l}\text { United Rys \& Electric Co. of Baltimore v West et al. } 280 \text { U.S. 234, } 50 \\
\text { S.Ct. } 123 \text { (1929) }\end{array}$ & Moody's \& Poor's \\
\hline $\begin{array}{l}\text { Commisioner of Banks v Chase Securities Corporation Brandegee v } \\
\text { Same, } 298 \text { Mass. 285, } 10 \text { N.E.2d } 472 \text { (1937) }\end{array}$ & Moody's \& Poor's \\
\hline $\begin{array}{l}\text { Pacific National Bank of Seattle v Commissioner of Internal Revenues, } \\
34 \text { B.T.A. } 8 \text { (1929) }\end{array}$ & Moody's \& Standard Statistics \\
\hline $\begin{array}{l}\text { Dallas Dome Wyoming Oil Fields Co. v Brooder, } 55 \text { Wyo. 109, } 97 \text { P.2d } \\
311 \text { (1936) }\end{array}$ & Moody's \& Poor's \\
\hline $\begin{array}{l}\text { Stanley Securitas Co. v. United States, } 69 \text { Ct.Cl. 271, } 38 \text { F.2d } 907 \\
\text { (1930) }\end{array}$ & Moody's \& Standard Statistics \\
\hline Taylor et al v Standard Gas \& Electric Co. et al. 96 F2d 693 (1938) & Moody's \& Standard Statistics \\
\hline
\end{tabular}

Source: Authors', from Westlaw

Last but not least, all variables of interest (incidence of quotations according to the type of information, capacity in which the agency acted, co-quotations etc.) were examined across time. 